\title{
ANALYSIS OF FACTORS RELATED TO THE OCCURANCE OF FALL IN ELDERLY
}

\author{
Puji Suwariyah*, Intan Diah Pramithasari \\ Nursing Study Program, Health Science of Serulingmas, J1. Raya Maos No. 505, Maos, Kampungbaru, \\ Karangreja, Cilacap, Kabupaten Cilacap, Jawa Tengah, Indonesia 53272 \\ * pujisuwariyah@yahoo.co.id
}

\begin{abstract}
Elderly is very susceptibleto fall in, this is because their all organ systems have decreased. The occurance of falls in the elderly is influenced by several factors such as age, environment, cardiovascular disorders, and physical activity. The writer wanted to analyze factors related to the risk of falling occurance in the elderly in the District Health Center of Maos, Cilacap Regency. This type of research is a correlational study with a cross sectional approach. The number of samples of this study were 52 elderly taken using consecutive sampling. The analysis used chi square test. The risk of falling occurance rates for the elderly in the Maos Community Health Center in Cilacap Regency was mostly in the no-risk category of 36 respondents $(69.2 \%)$. Chi square test results showed that there were age factors ( $\mathrm{p}$ 0.033), environment ( $\mathrm{p} 0,000)$, cardiovascular disorders ( $\mathrm{p} 0.011$ ), and physical activity ( $\mathrm{p}$ 0,000) with the risk of falling in the elderly in the Maos Puskesmas Area, Cilacap Regency. There is a relation between age, environment, cardiovascular disorders and physical activity with the risk of falling in the elderly in the Maos Puskesmas in Cilacap Regency.
\end{abstract}

Keywords: physical activity, cardiovascular disorders, falling risk

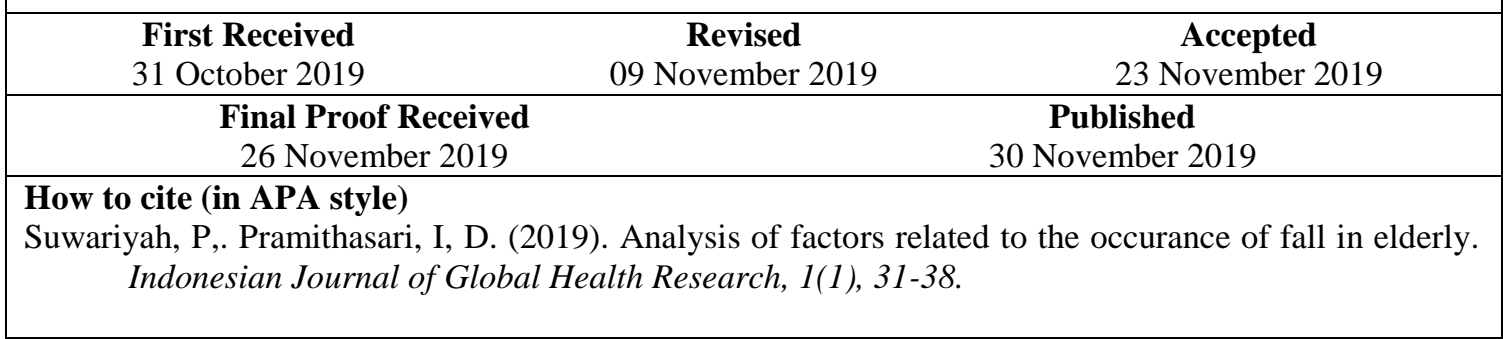

\section{INTRODUCTION}

Aging is a process when the ability of the network to repair itself / replace itself and maintain its normal structure and function is slowly decreasingtherefore it cannot withstand injury (including infection) and repair the damage suffered " (Constantinides, 1994) in (Darmojo, 2009). Elderly is very susceptible of falling, this is because all the organ systems in the elderly have decreased. Fall is an event that causes conscious subjects to be accidentally on the surface of the ground and it does not include falling due to hard blows, loss of consciousness, or seizures. The fall occurance is caused by a specific reason which types and consequences are different from those who are consciously experiencing a fall (Stanley \& Beare, 2007).

Sutomo's research results (2012) show that the intrinsic factor of elderly people (heart problems, movement disorders, CNS disorders, vision disorders, and hearing loss) is related to the risk of falls ( $\mathrm{p}$ value $<0.05$ ). There is a relationship with the risk of falling ( $\mathrm{p}$ value $<0.05$ ) with extrinsic factors (walking aids, environment). Situational factors (activity, history of disease) is related to the risk of falling at the WismaMulia Nursing Home in West Jakarta ( $\mathrm{p}$ value $<0.05$ ). 
Factor that can cause falls in the elderly are hearing loss. The inner ear consists of the cochlea and balance organs. The vestibular system together with the eye and propioseptor helps in maintaining the physical balance of the body or equilibrium. Disorders of the vestibular system can lead to dizziness and vertigo which can disturb balance (Mauk, 2014). Aside from hearing loss, cardiovascular disease such as heart failure can also cause a risk of falling in the elderly. According to Kane (1994) in (Darmojo R. B. M, 2009), that the incidence of congestive heart failure and myocardial infarction increases with age. Hypertension and cardia arrhythmias are also often found in the elderly. Disorders of the cardiovascular system will cause syncope. Syncope often causes falls in the elderly.

In addition to factors from within the elderly, external factors such as the environment also play a role in determining the risk of falls in the elderly. (Ashar, 2016) in his study stated that the environment is factors that can affect balance and contribute to the risk of falling, the incidence of falling in the room tend to occurs such as in the bathroom, bedroom, toilet, and kitchen. About $10 \%$ of falls often occur when going down stairs because it is more dangerous than going up stairs. Based on the description above, the authors are interested in conducting correlation research for Analyze the Factors Related to Falling Occurancein the Elderly in Maos Health Center, Cilacap Regency by using a cross sectional approach.

\section{METHOD}

This type of research is a correlational study with a cross sectional approach. The number of samples from this study were 52 elderly taken using consecutive sampling. The analysis used chi square test. Data obtained directly from the answers of respondents in the questionnaire that was given. The questionnaire was given to the elderly in the area of Puskesmas Maos during the Prolanis activities. The instruments used in this study were questionnaire sheets and research observations. Questionnaire sheets consist of data on name, age, gender, education, environment, cardiovascular disorders, physical activity and risk of falls. The researcher questionnaire adopted from the previous researcher so that the researcher did not do the validity and reliability test first. Fall risk questionnaire in the elderly using Morse Fall Scale (MFS).

\section{RESULTS}

Table 1.

Falling incident rate that occurred in elderly $(\mathrm{n}=52)$

\begin{tabular}{lcc}
\hline Fall Rate of Incidence & $\mathrm{f}$ & $\%$ \\
\hline No risk & 36 & 69,2 \\
Low risk & 9 & 17,3 \\
High risk & 7 & 13,5
\end{tabular}

Table 1 show that the risk of occurrence among elderly people in the MaosHealth Center in Cilacap Regency was mostly in the non-risk category as many as 36 respondents $(69.2 \%)$.

Table 2 shows that the results of the chi square test obtained a $\mathrm{p}$ value of 0.033 , meaning that there is an age factor with a risk of falling in the elderly in the Maos Community Health Center in Cilacap Regency. 
Table 2.

Relationship between the current age factor and the risk of falling occurance $(n=52)$

\begin{tabular}{|c|c|c|c|c|c|c|c|c|c|}
\hline \multirow{3}{*}{ Age(year) } & \multicolumn{6}{|c|}{ Risk of Fall Occurance } & \multirow{2}{*}{\multicolumn{2}{|c|}{ Total }} & \multirow[t]{3}{*}{$p$ value } \\
\hline & \multicolumn{2}{|c|}{ No risk } & \multicolumn{2}{|c|}{ Low risk } & \multicolumn{2}{|c|}{ High risk } & & & \\
\hline & $\mathrm{f}$ & $\%$ & $\mathrm{f}$ & $\%$ & $\mathrm{f}$ & $\%$ & f & $\%$ & \\
\hline $60-65$ & 23 & 63,9 & 3 & 33,3 & 2 & 28,6 & 28 & 53,8 & \\
\hline $66-71$ & 13 & 36,1 & 6 & 66,7 & 4 & 57,1 & 23 & 44,2 & 0,033 \\
\hline$>71$ & 0 & 0 & 0 & 0 & 1 & 14,3 & 1 & 1,9 & \\
\hline
\end{tabular}

Table 3.

Relation between current environmental factors and falling occurance $(\mathrm{n}=52)$

\begin{tabular}{|c|c|c|c|c|c|c|c|c|c|}
\hline \multirow{3}{*}{ Environment } & \multicolumn{6}{|c|}{ Risk of fall occurance } & \multirow{2}{*}{\multicolumn{2}{|c|}{ Total }} & \multirow{3}{*}{$p$ value } \\
\hline & \multicolumn{2}{|c|}{ No risk } & \multicolumn{2}{|c|}{ Low risk } & \multicolumn{2}{|c|}{ High risk } & & & \\
\hline & $\mathrm{f}$ & $\%$ & $f$ & $\%$ & $\mathrm{f}$ & $\%$ & $\mathrm{f}$ & $\%$ & \\
\hline No risk & 35 & 97,2 & 4 & 44,4 & 2 & 28,6 & 41 & 78,8 & \\
\hline Risky & 1 & 2,8 & 5 & 55,6 & 5 & 71,4 & 11 & 21,2 & 0,000 \\
\hline
\end{tabular}

Table 3 shows that the results of the chi square test obtained a $p$ value of 0,000 , meaning that there are environmental factors with a risk of falling in the elderly in Maos Health Center Cilacap Regency.

Table 4.

Relation between cardiovascular disorders factors of hearing loss and falling occurance $(\mathrm{n}=52)$

\begin{tabular}{|c|c|c|c|c|c|c|c|c|c|}
\hline \multirow{3}{*}{$\begin{array}{c}\text { Cardiovaskular } \\
\text { disorder }\end{array}$} & \multicolumn{6}{|c|}{ Risiko Kejadian Jatuh } & \multirow{2}{*}{\multicolumn{2}{|c|}{ Total }} & \multirow{3}{*}{$\begin{array}{c}p \\
\text { value }\end{array}$} \\
\hline & \multicolumn{2}{|c|}{ No risk } & \multicolumn{2}{|c|}{ Low risk } & \multicolumn{2}{|c|}{ High risk } & & & \\
\hline & $\mathrm{f}$ & $\%$ & $\mathrm{f}$ & $\%$ & f & $\%$ & $\mathrm{f}$ & $\%$ & \\
\hline No disorder & 33 & 91,7 & 5 & 55,6 & 4 & 57,1 & 42 & 80,8 & 0 \\
\hline Have disorder & 3 & 8,3 & 4 & 44,4 & 3 & 42,9 & 10 & 19,2 & 0,011 \\
\hline
\end{tabular}

Table 4 shows that the results of the chi square test obtained a $p$ value of 0.011 , meaning that there is a cardiovascular disorder factor with a risk of falls in the elderly in Maoshealth center, Cilacap Regency.

Table 5.

Relation between physical activity factors and falling occurance $(\mathrm{n}=52)$

\begin{tabular}{|c|c|c|c|c|c|c|c|c|c|}
\hline \multirow{3}{*}{ Physical Activity } & \multicolumn{6}{|c|}{ Risk of fall occurance } & \multirow{2}{*}{\multicolumn{2}{|c|}{ Total }} & \multirow{3}{*}{$\begin{array}{c}p \\
\text { value }\end{array}$} \\
\hline & \multicolumn{2}{|c|}{ No risk } & \multicolumn{2}{|c|}{ Low risk } & \multicolumn{2}{|c|}{ High risk } & & & \\
\hline & $\mathrm{f}$ & $\%$ & $\mathrm{f}$ & $\%$ & $f$ & $\%$ & $\mathrm{f}$ & $\%$ & \\
\hline Good & 35 & 97,2 & 3 & 33,3 & 4 & 57,1 & 42 & 80,8 & \\
\hline Not good & 1 & 2,8 & 6 & 66,7 & 3 & 42,9 & 10 & 19,2 & 0,000 \\
\hline
\end{tabular}

Table 5 shows that the results of the chi square test obtained a $p$ value of 0,000 , meaning that there is a factor of physical activity with the risk of falls in the elderly in the Maos Health Center in Cilacap Regency.

\section{DISCUSSION}

1. The incidence of falls that occur in the elderly who stay in the Maos Health Center Cilacap Regency.

The results of the study showed that the incidence of the risk of falling in the elderly in 
Maos Health Center CilacapRegency are mostly in the category of not at risk as many as 36 respondents $(69.2 \%)$. However, the results of the analysis showed there were $17.3 \%$ of respondents with a low risk of falling and $13.3 \%$ of the elderly with high risk. The risk of falls in the elderly goes upalong with increasing fall risk factors such as age, pathological conditions, and environmental factors. A person who grows older experiences many setbacks or morphological changes in muscles, that cause muscle functional changes, namely a decrease in muscle strength and contraction, muscle elasticity and flexibility, and speed in any case. Decreased muscle function and strength will result in a decrease in the ability to maintain balance in the elderly. There are several things that can cause postural imbalance or the balance of the human body, including the effects of aging, accidents, or due to illness factors (Junior, Deniro, Sulistiawati, \& Widajanti, 2017).

Dwi and Gunawan (2016) explains that the elderly are the final stage that every individual will go through because of the body's aging process. Someone who grows older will experience various setbacks in physical, psychological and social functions. Setbacks that occur in the elderly will cause health problems; one of them which isoften experienced by the elderly is the risk of falling. Fall is a sudden and accidental occurance that results in someone lying or sitting on the lower floor without losing consciousness (Maryam, 2010). (Miller, 2012) explains that falls are the result of a combination of several factors namely age, environment and pathological conditions. Elderly experience setbacks and changes in muscle shape that causes a decrease in muscle function that will lead to a decrease in strength and muscle contraction. Decreased muscle function and strength resulting in the ability of the elderly to maintain postural balance or body balance will decrease so that the elderly will easily experience a fall occurance.

2. Relation between age factors and the risk of falls in the elderly in the Maos Health Center in Cilacap Regency.

The results of the study showed that the results of the chi square test obtained a $\mathrm{p}$ value of 0.033 , meaning that there is an age factor with a risk of falling in the elderly in MaosHealth Center, Cilacap Regency. The body function decrease as a person ages. Reduced bodily functions are at risk of causing various problems, one of which is the risk of falls in the elderly. The results of this study are in line with the results of Ozturket. al., research (2017) that there is a relation between age and the incidence of falling in the elderly. The results of the analysis show that the risk of falling 1 time there is $65-79$ years as much as $60.8 \%$ while the risk of falling 2 times at age $>80$ years is $527.7 \%$.

The results of the analysis (Junior et al., 2017) showed that there was a significant low and direct relation between age and fall risk in the study subjects $(\mathrm{r}=0.334, \mathrm{p}<0.05)$. The results of the analysis show that as patients' ages, the higher percentage of risk of falling they have. As human grow older, they will experience a process of degeneration and a decrease in the ability to carry out activities of daily life, so that the possessed flexibility will decrease and cause a greater risk of falling. These results are supported by the results of the analysis of (Susilo, Limyati, \& Gunawan, 2017) showed that subjects at the age of 70-79 years were nine times more at risk of falling from ages 6069 years. 
3. Relationship between environmental factors and the risk of falls in the elderly in Maos Health Center, Cilacap Regency.

The results of the study showed that the results of the chi square test obtained $p$ value of 0,000 , meaning that there are environmental factors with a risk of falls in the elderly in the Maos Health Center Cilacap Regency. Environmental conditions are an important factor in the incidence of elderly falls. This is because the environment is a place for elderly to live and do the daily activities. The results of this study are in line with the results of Sofyan's study (2011), that there is a significant relation between the physical condition of the home environment and the incidence of falling in the elderly $(\rho<0.05)$.

The results of the analysis of (Hutomo, 2015) showed that the arrangement of an unsafe elderly home environment has a 10-11 times more likely to experience a fall, compared to a safe structured home environment. Kane (1994) in (Darmojo R. B. M, 2009) explains that the environment that is often associated with falling in the elderly includes household appliances that are old or lying underneath, unstable beds or low and slippery bathrooms, fragile handle, the unstable, slippery or steep floor, the carpet that is not glued properly, thick mat with bent edges and floor mat that is slippery or easily displaced, the slippery and wet floor and thebad lighting (less or dazzling).

4. Relation between cardiovascular disorders hearing loss with the occurance of falls in the elderly in Maos Health Center Cilacap Regency.

The results of the study showed that the results of the chi square test obtained $p$ value of 0.011, meaning that there are cardiovascular disorders with the risk of falls in the elderly in the MaosHealth Center, Cilacap Regency. Cardiovascular disorders experienced by the elderly will disturb their activities, even at risk of causing falls. It is because the function of the cardiovascular system is to provide and supply oxygen and nutrients to all tissues and organs of the body that are needed in the metabolic process. The cardiovascular system also functions as a regulatory system performing various mechanisms in response to bodily activities, such as the mechanism of increasing blood oxygen supply so that tissue activity can be fulfilled (Muttaqin, 2009).

The results of this study are in line with the results of the study by (Freilich \& Barker, 2009) that there is a relation between cardiovascular disorders and the risk of falling in patients. These results are also supported by the results of Ozturket. al.,research (2017) that there is a relation between a history of chronic (cardiovascular) disease with the occurance of falls in the elderly. The most chronic disease that causes falls is cardiovascular disease, which falls 1 time $50.9 \%$ and more than 1 time $49.1 \%$.

5. The relation of physical activity factors with the occuranceof falls in the elderly in Maos Health Center, Cilacap Regency.

The results of the study showed that the results of the chi square test obtained $p$ value of 0,000 , meaning that there is a factor of physical activity with the risk of falls in the elderly in the MaosHealth Center of Cilacap Regency. The elderly physical activity has an important role in maintaining the flexibility and balance of their body. Elderly with less activity are at risk for falling. The results of this study are in line with the results of Gunawan's research (2016) that there is a relation between physical activity and the risk of falling in the elderly with a p-value $=0.010(p<0.05)$. (Susilo et al., 2017). 
These results are supported by the research results of Deniro et al. (2017) that there is a moderate and unidirectional significant relationship between daily activities and the risk of falling in research subjects $(r=-0.460, p<0.01)$. From the results of the analysis it can be seen that the more independent the patient is in carrying out daily activities, the more tendency they have decreasing high risk of fall occurance. This is also supported by the results of (Sari, 2015) that there is a relation between the levels of independence of daily activities with the risk of falling in the elderly. The level of independence is very necessary for the elderly because independently the elderly can do their own activities without asking for help from others and can strengthen their joints.

\section{CONCLUSION}

The risk of falling occurance rates for the elderly in the MaosHealth Center Cilacap Regency is mostly in the no-risk category of 36 respondents (69.2\%). There is an age factor with a risk of falling in the elderly in the MaosHealth Center in Cilacap Regency with a $\mathrm{p}$ value of 0.033 . There are environmental factors with a risk of falling in the elderly in the Maosealth Center in Cilacap Regency with a p value of 0,000. There are cardiovascular disorders with the risk of falls in the elderly in the MaosHealth Center in Cilacap Regency with a $\mathrm{p}$ value of 0.011 . There is a physical activity factor with the risk of falling in the elderly in the MaosHealth Center in Cilacap Regency with a $p$ value of 0,000 .

\section{ACKNOWLEDGEMENT}

For Maos Health Center, Cilacap Regency, it is hoped that the results of this research can be used as information material to improve health services, especially in assessing the risk of falling in the elderly and implementing the elderly and families regarding the prevention of falls themselves. For Families, it is expected that the family to be more careful and supervise the elderly who have a risk of falling by providing a safe and comfortable environment and accompanying the elderly when doing physical activities that can cause falls. For further researchers, it is hoped that this research can be further investigated and developed using other variables that can affect the risk of falls such as drug use, vision problems using a different design.

\section{REFERENCES}

Ashar, P. H. (2016). Gambaran Persepsi Faktor Risiko Jatuh Pada Lansia Di Panti Werdha Budi Mulia 4 Margaguna Jakarta Selatan (Universitas Islam Negeri Syarif Hidayatullah Jakarta). Retrieved from repository.uinjkt.ac.id > dspace > bitstream

Darmojo R. B. M. (2009). Geriatri (Ilmu Kesehatan Usia Lanjut) Edisi ke-3 (3rd ed.). Jakarta: Balai Penerbit FKUI.

Dwi, J., \& Gunawan, A. (2016). Hubungan Antara Aktivitas Fisik Dengan Risiko Jatuh Pada Lanjut Usia Di Desa Pucangan Kecamatan Kartasura (Universitas Muhammadiyah Surakarta). Retrieved from http://eprints.ums.ac.id/44687/25/NASKAH PUBLIKASI.pdf

Freilich, S., \& Barker, R. (2009). Predicting Falls Risk in Patient - The Value of Cardiovascular Variability Assessment. British Journal of Medical Practitionerrs, 2, 44-48. Retrieved from https://www.bjmp.org/content/predicting-falls-risk- 
patients-value-cardiovascular-variability-assessment

Hutomo, A. K. (2015). Hubungan Penataan Lingkungan Rumah Terhadap Risiko Jatuh Pada Lansia Di Desa Karangwuni Wates Kulon Progo. Retrieved from http://digilib.unisayogya.ac.id/51/1/NASKAH PUBLIKASI.pdf

Junior, A., Deniro, N., Sulistiawati, N. N., \& Widajanti, N. (2017). Hubungan antara Usia dan Aktivitas Sehari-Hari dengan Risiko Jatuh Pasien Instalasi Rawat Jalan Geriatri The Relationship between Age and Activity of Daily Living with the Fall Risk of Patients in Geriatric Outpatient Installation. In Jurnal Penyakit Dalam Indonesia $\mid$ (Vol. 4).

Maryam, R. S. (2010). Asuhan Keperawatan pada Lansia. Jakarta: Trans Info Medika.

Mauk, K. L. (2014). Gerontological Nursing: Compentencies for Care (3rd ed.). Jones $\&$ Bartlett Learning.

Miller, A. . (2012). Nursing Care of Older Adult Theory and Practice. Philadelpia: J.B. Lippincott.

Sari, Y. P. (2015). Hubungan Tingkat Kemandirian Aktivitas Sehari-hari Dengan Risiko Jatuh Pada Lansia Di PSTW Unit Budhi Luhur Kasongan Bantul Yogyakarta (Stikes Aisiyah $\quad$ Yogyakarta). Retrieved from http://digilib.unisayogya.ac.id/183/1/Naskah Publikasi_Yulinda P.S $\% 28201110201069 \% 29 . p d f$

Stanley, M., \& Beare, P. G. (2007). Buku Ajar Keperawatan Gerontik (2nd ed.). Jakarta: EGC.

Susilo, W., Limyati, Y., \& Gunawan, D. (2017). The Risk of Falling in Elderly Increased with Age Growth and Unaffected by Gender. In Journal of Medicine and Health Risk of Fall on Elderly (Vol. 1). 
Indonesian Journal of Global Health Research, Vol 1 No 1, November 2019, pp. 31 - 38 Global Health Science Group 